\title{
Vision in fossilised eyes
}

\section{Brigitte Schoenemann ${ }^{1,2}$ and Euan N. K. Clarkson ${ }^{3}$}

\author{
${ }^{1}$ University of Cologne, Department of Education, Seminar for Zoology, Gronewaldstrasse 2, D-50931 Köln, \\ Germany. \\ ${ }^{2}$ University of Cologne, Institute of Zoology, Department of Animal Physiology, Biocenter Cologne, \\ Zülpicherstrasse 47b, D-50674 Köln, Germany. \\ Email: B.Schoenemann@uni-koeln.de \\ ${ }^{3}$ Grant Institute, School of Geosciences, The King's Buildings, University of Edinburgh, West Mains Road, \\ Edinburgh EH9 3JW, Scotland, UK. \\ Email: Euan.Clarkson@ed.ac.uk
}

\begin{abstract}
This paper presents a review of recent developments in the study of vision in fossil arthropods, beginning with a discussion of the origin of visual systems. A report of the eyes of Cambrian arthropods from different Lagerstätten, especially the compound and median arthropod eyes from the Chengjiang fauna of China, is given. Reference is made also to compound eyes from the lower Cambrian Emu Bay Shale fauna of Australia and the Sirius Passet fauna of Greenland; also to the three-dimensionally preserved 'Orsten' fauna of Sweden. An understanding of how these eyes functioned is possible by reference to living arthropods and by using physical tools developed by physiologists. The eyes of trilobites (lower Cambrian to Upper Permian) are often very well preserved, and the structure and physiology of their calcite lenses, and the eye as a whole, are summarised here, based upon recent literature. Two main kinds of trilobite eyes have been long known. Firstly, there is the holochroal type, in which the lenses are usually numerous, small and closely packed together; this represents the ancestral kind, first found in lowermost Cambrian trilobites. The second type is the schizochroal eye, in which the lenses are relatively much larger and each is separated from its neighbours. Such eyes are confined to the single suborder Phacopina (Lower Ordovician to Upper Devonian). This visual system has no real equivalents in the animal kingdom. In this present paper, the origin of schizochroal eyes, by paedomorphosis from holochroal precursors, is reviewed, together with subsequent evolutionary transitions in the Early Ordovician. A summary of new work on the structure and mineralogy of phacopid lenses is presented, as is a discussion of the recent discovery of sublensar sensory structures in Devonian phacopids, which has opened up new dimensions in the study of trilobite vision.
\end{abstract}

KEY WORDS: Cambrian arthropods, holochroal, origins of vision, schizochroal, sublensar structures, trilobites

The origin of vision lies far back in time, but there is still great uncertainty about how this critical event took place. There is a general consensus, however, that the origin of visual systems formed part of the so-called Cambrian Explosion; the great phenomenon that took place around 541 million years ago (Ma), when during a short stretch of time, only ca. 10-20 million years, almost all of the phyla we know today appeared. During the preceding Ediacaran, there is no unequivocal evidence of predation, thus vision was not needed for detecting predators or prey. In the lower Cambrian, animals developed harder shells, predators arose, and there began an arms race between predators and prey. The need 'to see' and 'to be seen' or 'not to be seen' triggered rapid evolution and helped shape the dynamics of ecological systems (Parker 2003).

Several interesting models have been produced showing how the earliest eyes may have developed. But how, exactly, can we define what an eye actually is? Some nerve cells are highly sensitive to light, but even a specialised light-sensory cell does not, by itself, produce vision, especially if there is just one single cell. Following the definitions of Land \& Nilsson (2012) and Cronin et al. (2012), a 'real' eye should provide information about the contrast distribution of illuminated objects in the environment. A well-developed eye makes it possible to detect mates or food, gives information about the physical properties of the environment, enables orientation and, not least, movement discrimination, and will allow the detection of predators. Whereas this definition normally involves associated brain function from any visual input, we have to consider also box-jellyfish, which are equipped with elegant lens-eye systems, and can visually hunt fish, but have no brain or even a central ganglion.

Darwin's original idea about the origin of vision involved a single light-sensitive cell, which is shielded at one side by a pigment cell (Fig. 1a) from one original cell by unequal division of the pigment granules contained within it (Darwin 1859; Gehring 2005; Gehring \& Seimiya 2010). The pigment cell shades the sensory cell from one side, so that a directional sensitivity arises. Diurnal rhythms, vertical migrations during the day, positive or negative phototaxis, and movement towards or away from a light source, as are very common in small organisms, thus becomes possible. If both cells divide several times, a small patch of light-sensitive cells and their screening partners arises, a so-called 'eye spot' (Fig. 1b, c). These systems are very frequent amongst invertebrates and even exist in chordates such as Branchiostoma lanceolatum (Pallas, 1774). They can, however, as in the original two-cell system, inform 
(a)<smiles>c1ccccc1</smiles>
$\Rightarrow$

(b)

(c)

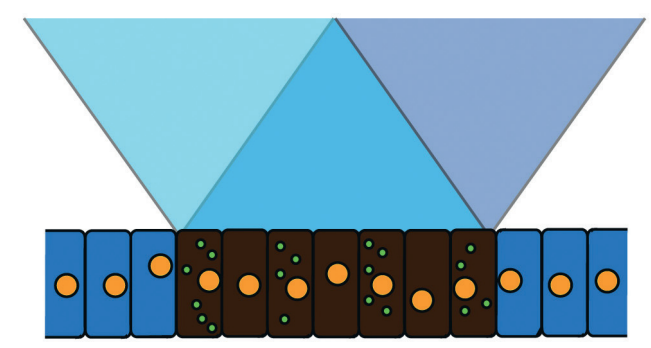

(d)

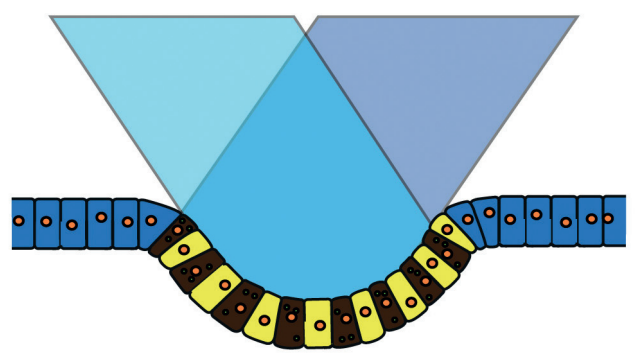

(e)
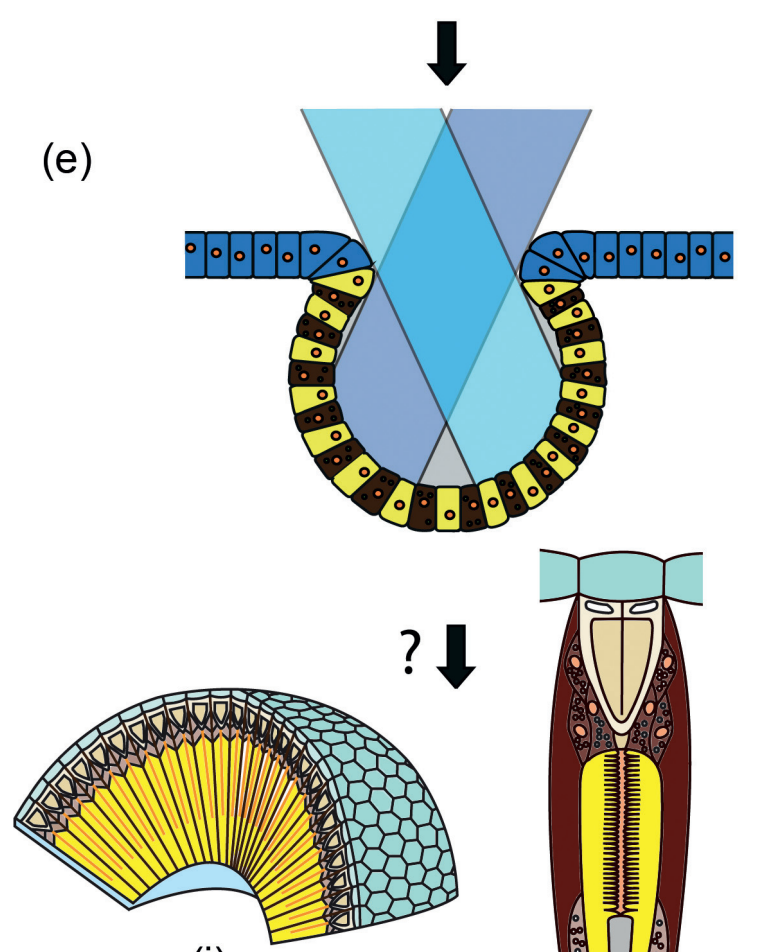

(i)

\section{$\downarrow$}

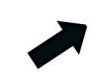

(g)

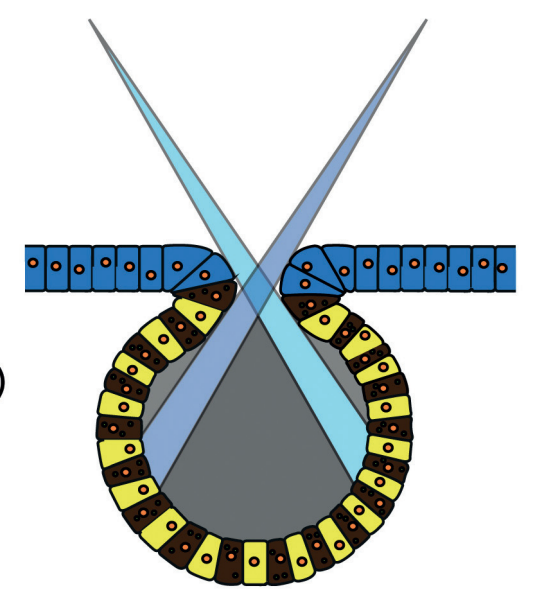

(h)

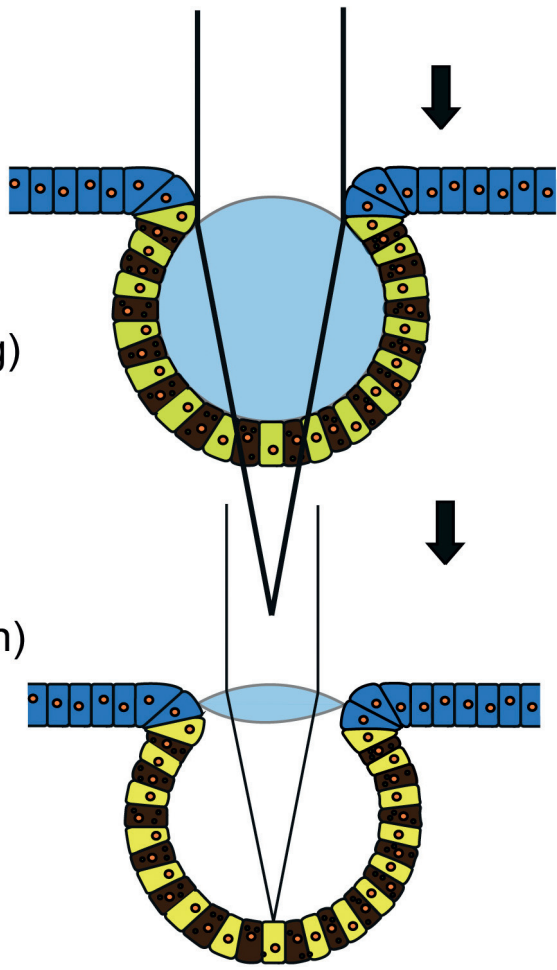

Figure 1 Origins of visual systems from a simple light-sensitive cell. For explanation see text: (a) cell with asymmetric distribution of pigments in the plasma; (b) unequal cell division, arising from a pigment and sensory cell; (c) spot eye, which cannot distinguish the direction of the incident light, but can sometimes distinguish movements, if one sensory cell after the other is shadowed by a passing object; (d) pit eye; (e) deepened pit eye (cup eye), detection of direction is possible; (f) pinhole camera eye, image formation is possible; (g) simple lens eye, under-focusing; (h) camera lens eye with high light performance; (i) compound eye (focal apposition type); (j) unit of compound eye - ommatidium (focal apposition type). 
their bearers only about the presence or absence of light and its intensity. These, then, are not 'real' eyes, but they do provide enough information to enable the establishment of diurnal rhythms, or allow movements towards or away from light sources; in other words, phototaxis. Directionality is achieved, as soon as the eye spot is deepened to become a pit (Fig. 1d), and obliquely entering light rays are shadowed by one side of the pit. The deeper the pit, the better the direction can be distinguished. The final stage is when the pits become more or less spherical (Fig. 1e). These can then start to form inverted images - in wide open pits these images are still blurred, but the smaller the opening, the sharper the images become, but also less light reaches the small retina at the base. The 'invention' of a lens solves this problem. Here, a small mucous lens sits inside the pit, directly onto the retina (Fig. 1f). Systems of this kind are the so-called ocelli. Ocelli occur in many invertebrates (worms and molluscs for example), but also in arthropods as larval eyes (stemmata), or as median eyes that characterise all euarthropods. There exist several models, attempting to explain how more complex eyes developed following this stage, such as the camera eyes of humans or cephalopods, with a vitreous body that allows sharp focusing (Fig. 1g), or the compound eyes of arthropods (Fig. 1h) and polychaetes (Gehring 2005; Nilsson 2009; Gehring \& Seimiya 2010).

Institutional abbreviation. RCCBYU, Research Centre for the Chengjiang Biota, Yunnan University.

\section{Ancient eyes in the fossil record}

\subsection{Cambrian arthropods}

The fossil record reveals a remarkable amount of information about ancient visual systems. For example, Tanaka et al. (2009) showed that superposition compound eyes were present in an Eocene fly preserved in amber, and the same authors (Tanaka et al. 2014) recently found rods and cones in a 300 million-year-old (Upper Carboniferous) fish, Acanthodes bridgei Zidek, 1976 that are suggestive of colour. There was a great Palaeozoic diversification of different kinds of eye, especially in the Ordovician, and particularly those of trilobites. These come mainly from the early to late Cambrian (Ramsköld et al. 1997; Schoenemann \& Clarkson 2010, 2012a, b, c, 2015; Paterson et al. 2011; Schoenemann et al. 2011, 2014; Lee et al. 2012). Moreover, even internal sensory structures have been described recently from the compound eyes of Devonian trilobites (Schoenemann \& Clarkson 2013).

The organisms that appeared during the early Cambrian were already highly diversified, as also were the designs of their visual systems. Single-lens-eye systems are very clearly evident in the ocelli of lobopodians (Schoenemann et al. 2009). Their close relatives are the Recent onychophorans, and both share characteristics of arthropods and also of polychaete worms. Their eyes consist of thick lenses that sit on a cup filled with retinal and pigment cells. As is normal for ocelli, these single-lens eyes under-focus, which means that the incoming light is focused, but the image plane lies below the retinal surface, and thus the image perceived is blurred. Such an eye functions as a low-pass filter of spatial frequences, which means that only large-scale patterns of the environment can be distinguished, whilst details such as plankton or floating organic particles cannot be seen. It is easy to understand, however, that this kind of visual system provides the lobopodian with all that it needs to see - mates perhaps, physical patterns of the environment such as food, and predators moving around. Other single-lens systems may occur in early chordates, such as Haikouella lanceolata Chen, Huang \& Li, 1999 or vertebrates, such as Myllokunmingia (Shu, Zhang \& Han, 1999 in Shu et al. 1999), but whether their eyes are ocelli or already real camera eyes with a vitreous body, and thus a sharp imaging, awaits further research.

One of the best preserved Cambrian faunas is represented in the so-called Chengjiang Biota at multiple fossil sites close to Chengjiang in China (Hou et al. 2004). The age of this Konservat-Lagerstätte is Nangaoan, which correlates with the Atdabanian Stage of Siberia and is thus part of the traditional lower Cambrian dating around $520 \mathrm{Ma}$ (Rozanov et al. 2008; Zhang et al. 2008). The famous middle Cambrian Burgess Shale fauna from the Canadian Rockies consists of similar, but slightly younger forms when compared to the Chengjiang fauna, and dates back to about $505 \mathrm{Ma}$ (Briggs et al. 1994). The Emu Bay Shale biota (dated as Cambrian Series 2, Stage 4, about $515 \mathrm{Ma}$; Paterson et al. 2016) closely resembles the fauna of Chengjiang, but is not as well preserved. Still under discussion is the precise correlation of these Lagerstätten with the Sirius Passet organisms (e.g., Peel \& Ineson 2011). This location in northern Greenland is older than that of the Burgess Shale, but younger than the Chengjiang Fauna (Peng et al. 2012); it is rather loosely dated to 518-505 Ma (Martin et al. 2000).

Almost half of the species represented in the Chengjiang Fauna consist of arthropods, and the characteristic visual systems for arthropods are compound eyes. This is true for both stem- and crown-group euarthropods, whilst the latter, as is normal, possess (four) median eyes, which are the 'ocelli' mentioned above. The compound eyes of the Chengjiang fauna have been the subject of a number of investigations (Schoenemann \& Clarkson 2010, 2012a, b, c). Amongst the Chengjiang Fauna there are two types of compound eyes. The first type shows spherical optical units, and can be found in the genera Isoxys Walcott, 1890, Leanchoilia Walcott, 1912, some anomalocaridids and others. Hexagonal facets in densely packed compound eyes (as known from modern crustaceans and insects such as dragonflies or bees) are represented, for example, in Cindarella eucalla (Ramsköld et al. 1997; Schoenemann \& Clarkson 2012a, b, c; Zhao et al. 2013). We find the same in an assumed anomalocaridid from Emu Bay (Paterson et al. 2011), an unidentified arthropod (Lee et al. 2011), and some excellently preserved crustaceans from the Upper Cambrian Orsten biota (Schoenemann et al. 2011, 2014; Parker et al. 2013; Schoenemann 2013).

An understanding of how these eyes functioned is possible with reference to the visual systems of living arthropods. A typical focal apposition eye can consist of a few identical units (ommatidia), or up to several thousand. Each of these consists of a corneal lens, covering a so-called crystalline cone, which consists of clear cells giving space to the incident light focused by the lens. This is collected on the tip of a light guiding structure, the rhabdom. It is part of the sensory cells, and contains the visual pigments. The incident light changes the steric conformation of these pigments, which evokes an electrical signal that can be processed by the nervous system and results in 'vision'. Because the contrasts inside the visual field of each ommatidium are combined onto the tip of the rhabdom, and because all individual ommatidia are isolated against their neighbours by pigment cells, over the total compound eye a mosaic-like image of vision is formed. The resolution of this vision is partly related to the number of ommatidia, likened to the number of pixels in a computer graphic. Nowadays, this system is found abundantly in modern diurnal crustaceans and insects, namely in dragonflies or bees.

In the earliest upper Cambrian Alum Shales of Sweden, 'Orsten' limestone nodules can be found dated to the Agnostus pisiformis Biozone (for an overview see Müller 1983; Müller \& Walossek 1985). They contain phosphatised, three-dimensionally 


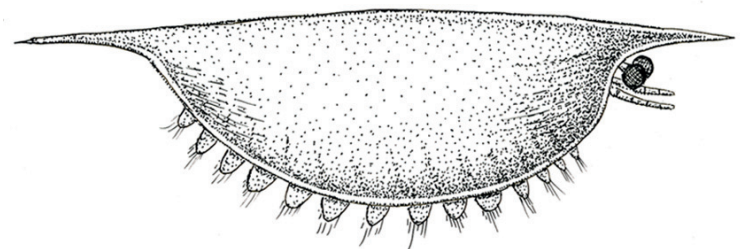

(a)
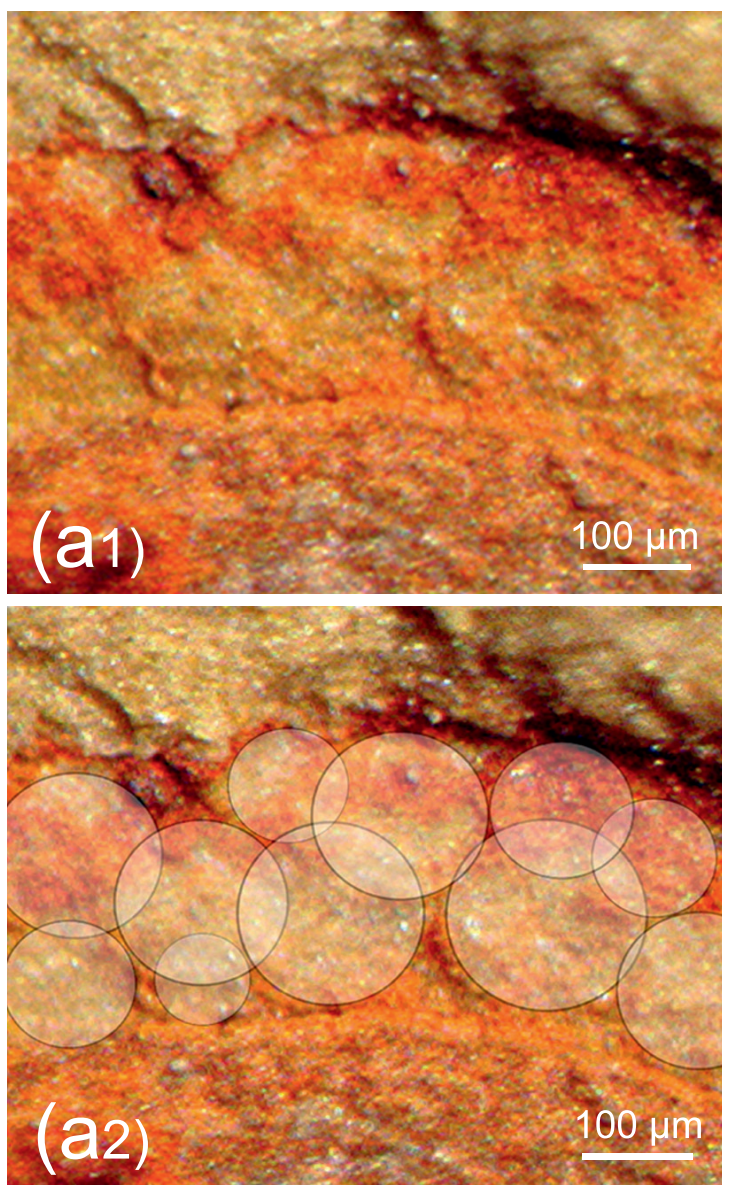

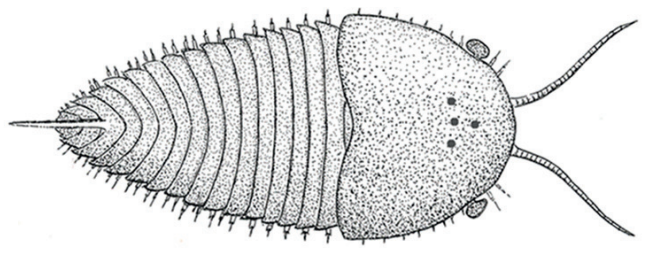

(b)
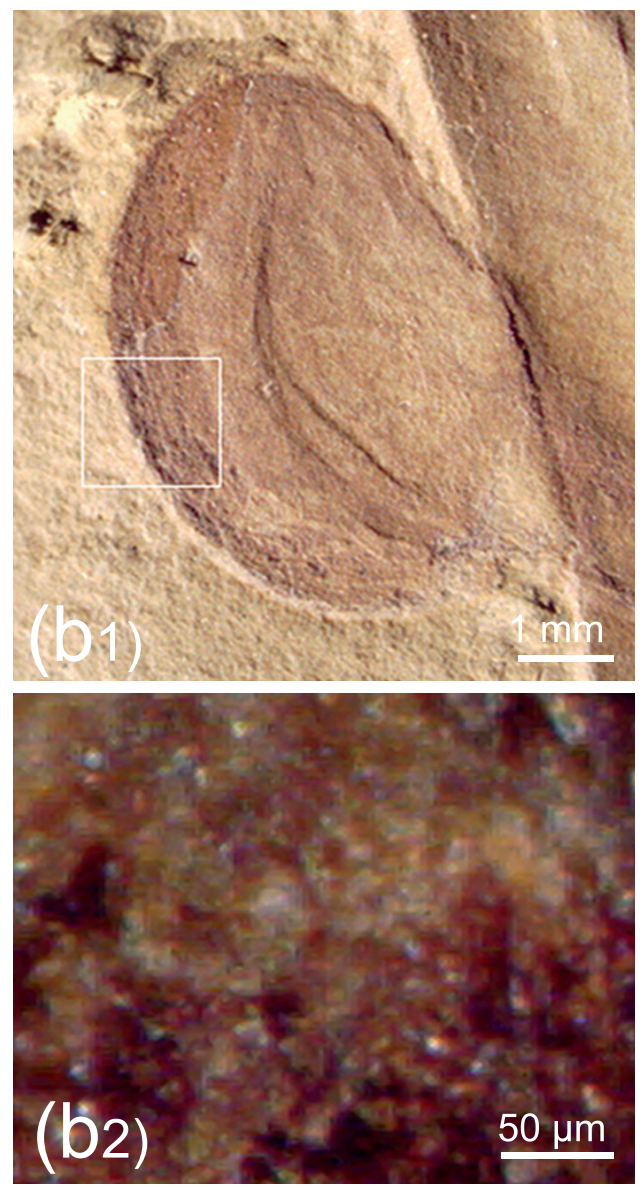

Figure 2 Vision in Cambrian arthropods. (a, a1, a2) Isoxys auritus (Jiang, 1982): (a) reconstruction, based on Vannier \& Chen (2000) and Hou et al. (2004); (a1) compound eye, specimen RCCBYU 10262, Maotianshan, Kunming, China, Lower Cambrian; (a2) visual units of a1 marked. (b, b1, b2) Cindarella eucalla Chen, Ramsköld et al., 1997: (b) reconstruction based on Ramsköld et al. (1997); (b1) compound eye, specimen RCCBYU 10288, Maotianshan Shale Member at Mafang, Haikou; (b2) individual facets from b1.

preserved crustaceans and other fossilised organisms that present finest details, such as bristles and compound eyes. Analysis of these eyes has shown that these early crustaceans possessed focal apposition eyes (Schoenemann 2013; Schoenemann et al. 2014), with a structure comparable to that of modern diurnal arthropods such as bees. Parker et al. (2013) were able to show that amongst these crustaceans, a sophisticated yellow cornea had been developed, filtering blue scattering light and enhancing the contrast underwater. Finally, the concept of an effective arrangement of facets in a compound eye, which was too small to supply an image, but able to detect small objects in a kind of sophisticated three-dimensional coordinate system (Schoenemann et al. 2011), has given clear insights into how elegant and sophisticated the visual systems of crustaceans had already become during Cambrian times.

In aquatic systems, the difference between the refractive indexes of water and the organic material is so low that the thin corneal lens has hardly any refractive power, and in modern systems the crystalline cone often takes over the refraction by forming cylinders with index gradients. Lenses with the highest refractive power are spherical, and this may be the reason the dioptric elements are globular in the Cambrian arthropod Isoxys and others (Fig. 2).

The elements of trilobite eyes seen in Figure 3 are almostspherical lenses. Similar systems in which the crystalline cone, functioning as a refractive unit, appears almost spherical are found in many modern crustacean eyes of today, such as those of isopodes or many amphipodes. The more advanced systems seem to be densely packed with the hexagonal facets mentioned above. Optimal dense packing of originally spherical systems results in hexagons, as we know, for example, in the combs of honey bees. Although the high number of facets leads to an enhanced acuity, the small lens-apertures impose constraints on visual function, because of the lower number of photons that can reach the sensory cells. The internal structure of these fossilised compound eyes, however, remains as yet unknown. 
Median eyes, which are a synapomorphy of all euarthropods, can be found in bearers of both systems (e.g., Cindarella and Leanchoilia; Fig. 2), and it seems clear that the same systems, whether equipped with spherical optical elements or as compound eyes with densely packed hexagonal facets, are still present in modern and advanced organisms, still living today.

Physiologists such as Snyder, Land, Nilsson and others have developed physical tools for describing the light ecological adaptations of living arthropods (Horridge 1977, 1978; Snyder 1977, 1979; Snyder et al. 1979), because the geometry of their compound eyes allow conclusions about how they process the incident light. Many of these tools can be applied, sometimes in a modified form, to fossils, and this allows an assignment to their ecological habitat and, in particular, the relative depth of the ocean they inhabited. This has been undertaken for the Chengjiang fauna (Schoenemann \& Clarkson 2010, 2011, 2012a, b, c) and Emu Bay eyes (Lee et al. 2011; Paterson et al. 2011), and also for the excellently preserved arthropods of Bundenbach (Lower Devonian, Hunsrück Shale), which could be assigned to waters up to $200 \mathrm{~m}$ depth (Rust et al. 2016), as well as for eurypterids (Anderson et al. 2014; Poschmann et al. 2016) and for a variety of trilobites (Fordyce \& Cronin 1989, 1993; McCormick \& Fortey 1998; Schoenemann et al. 2008a, 2010; Schoenemann \& Clarkson 2015; Tanaka et al. 2015). Other visual systems in the fossil record, such as those of the Carboniferous shrimps Tealliocaris (Briggs \& Clarkson 1985), remain to be investigated.

\subsection{Trilobites}

Trilobites are extinct marine arthropods that dominated the Palaeozoic. The earliest trilobites appeared, however, at the base of the Atdabanian (Cambrian Series 2, Stage 3; ca $521 \mathrm{Ma}$ ).

Following the early work of Clarke (1889) and Lindström (1901) on the structure of trilobite eyes, much has been written about them since the 1960s, and various summaries have been presented (e.g., Campbell 1975; Clarkson 1975, 1997; LeviSetti et al. 1998; Clarkson et al. 2006, 2008; Levi-Setti 2014). Here, our intention is to give an account of recent developments, especially in our understanding of the structure and functioning of these eyes.

1.2.1. A brief history. The earliest of all trilobites from the lowermost Cambrian Series 2 (c. $521 \mathrm{Ma}$ ) were equipped with compound eyes on their first appearance in the fossil record, as were the great majority of trilobites throughout the whole time span of this group. Indeed, the very last trilobites from the end Permian (c. 252 Ma), (Clarkson 1998; Fortey \& Owens 1977) had eyes not externally dissimilar to those of the early Cambrian trilobites (Feist \& Clarkson 1989). Whereas the origin of trilobites remains mysterious, it is well known that, very early in their history, these marine arthropods rapidly spread all over the world and colonised many environments, in deep and shallow waters of the continental shelves (Clarkson 1998). There was a continuous increase of trilobite genera and species throughout the Cambrian, though many of them remained benthic (Webster 2007). Following a major crisis at the end of the Cambrian, trilobites recovered and quickly diversified, colonising various environments including reef, pelagic and deep-water habitats (Clarkson 1998; Rudkin et al. 2003). The Ordovician was the acme of the trilobites, a time when they diversified more extensively than at any other time in geological history, with the greatest degree of morphological disparity (Adrain et al. 1998), and there was also a corresponding expansion in the number of eye types. During the latest Ordovician, the short-lived but severe Hirnantian glaciation had serious effects on the trilobites (Adrain et al. 1998), as it did on most other marine invertebrates (Sheehan 2001). Many morphotypes disappeared for ever, and some ecological niches, such as the pelagic realm, lost many typical trilobite inhabitants. Moreover, no radically new body plans originated after the early Ordovician, and trilobite evolution thereafter was no more than a matter of variation on themes established at that time.

The Silurian and Devonian history of the trilobites, though they still remained abundant and diversified in some environments, was a case of a long slow decline (Fortey \& Owens 1977). The Silurian faunas are basically an impoverished relic of types established in the early Ordovician. Those of the Devonian are rich and diversified in some parts of the world, such as Morocco (Chatterton et al. 2006; McKellar \& Chatterton 2009) and Algeria (Crônier et al. 2013; Khaldi et al. 2016) and, indeed, there were some distinctive adaptive radiations (Crônier \& Courville 2003; Crônier \& François 2014). Otherwise, it was a matter of stepwise extinction of one group after another. The late Devonian trilobite crises (Feist 1991; Clarkson 2013) disposed of all remaining groups, save for those of the Order Proetida, which continued throughout the whole of the Carboniferous and Permian until their final extinction over 90 million years later. During this time, they remained relatively small and had a conservative morphology, with the various genera not greatly different from one another. In addition, they were restricted to relatively few habitats, but to these they were well adapted. The great end-Permian crisis finally terminated a history of some 270 million years.

1.2.2. Holochroal eyes. It has always been recognised that there are two main types of compound eye in trilobites, with some possibility of a third type (Zhang \& Clarkson 1990, 1993, 2012). Holochroal eyes are apomorphic for trilobites and are the primary kind from which all variations were derived (Clarkson et al. 2006). These eyes are first found in the lower Cambrian, but persist in various manifestations until the final extinction of the trilobites at the end of the Permian. Holochroal eyes (Fig. 3a-c) are typically kidney-shaped, and often have two components. First there is the lens array, which consists of many small contiguous lenses of calcite, forming a curving visual surface which surveys a substantial field of view. Secondly, the visual surface is often typically set on a socle at the base (Schoenemann et al. 2010). The basic structure of the holochroal eye was remarkably conservative; the earliest Cambrian eyes are not externally dissimilar from those of the PermoCarboniferous.

Evolution in holochroal eyes was very much a matter of permutations on a basic theme established during the lower Cambrian. These variations include the size of eye, its shape, the number of lenses and their diameter and convexity. Trilobites with thick shells, such as the asaphids, tend to have long cylindrical lenses, whereas in olenids and other 'thin-shelled' trilobites, the lenses are slim and usually biconvex (Clarkson 1979). In all trilobite lenses, the use of simple Gaussian formulae enables the focal length of the lenses to be established (Clarkson 1979). In general terms, the relative curvature of the surfaces ensures that the focal point lies at about the same general distance below the base of the eye. The largest eyes are found in Ordovician pelagic trilobites, such as Opipeuterella, Telephina and Cyclopyge (Fortey 1985, 2000). In these forms, the two eyes may be fused anteriorly, and the visual field may be panoramic, extending ventrally as well as laterally and dorsally.

It may be assumed that below each lens in the holochroal eye there lies an ommatidium-like unit; the main difference between the eyes of a crustacean and those of a trilobite is that the crustacean lenses are organic, whereas trilobite lenses are composed of calcite. A current investigation of new material of some lower Cambrian trilobites is revealing sublensar structures for the first time.

1.2.3. New developments in the study of holochroal eyes. Magnificent new colour illustrations by Levi-Setti (2014) serve 

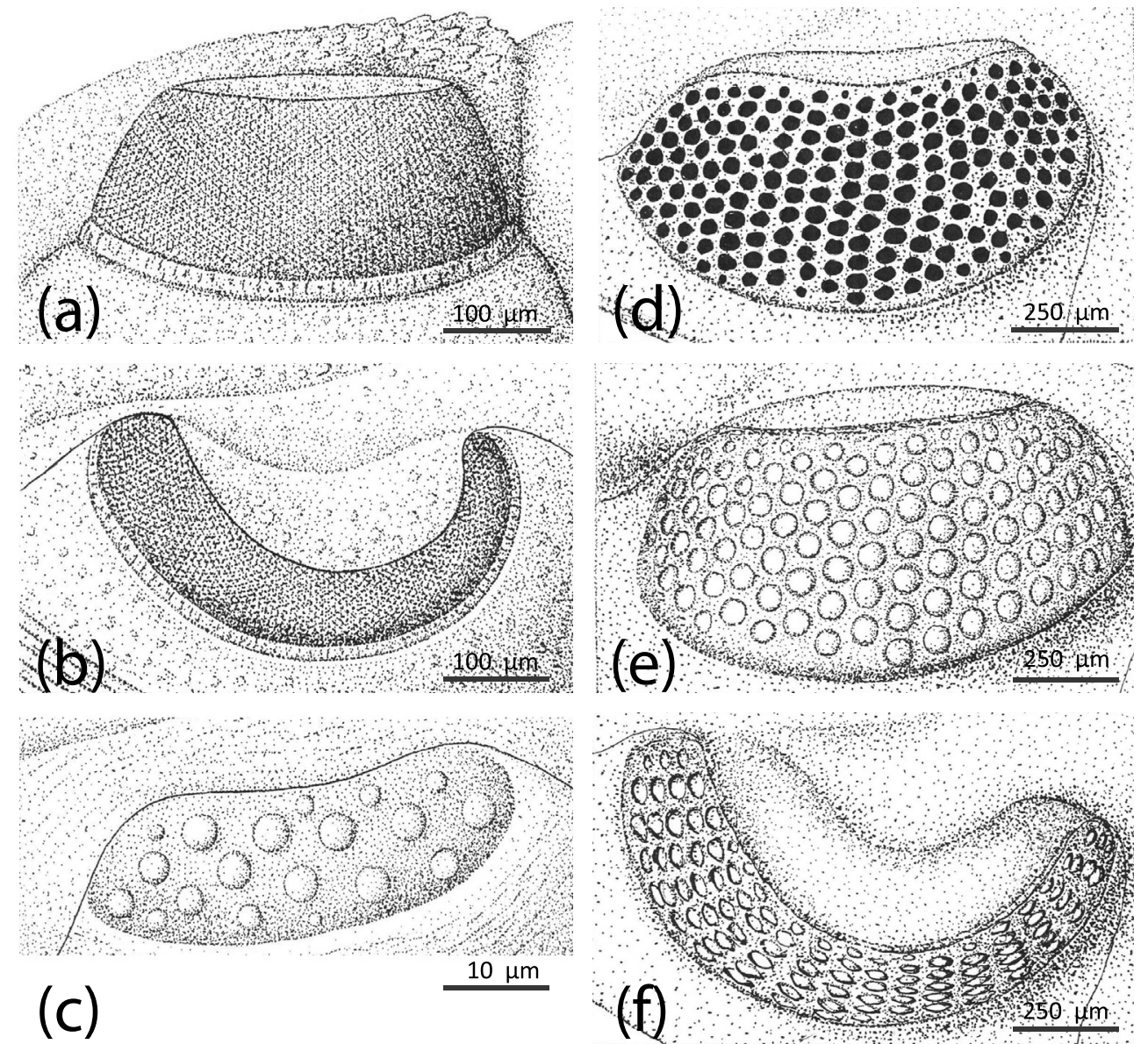

(c)

$10 \mu \mathrm{m}$

Figure 3 Holochroal and schizochroal eyes. (a-c) Holochroal eyes of Paladin eichwaldi shunnerensis (King, 1914), middle Carboniferous, Yorkshire, England. Left holochroal eye of an adult in (a) lateral (b) dorsal views; (c) juvenile eye of a degree 0 meraspis. All based on Clarkson \& Zhang 1991. (d) Adult schizochroal eye of Ormathops atavus (Barrande, 1872), early Ordovician, showing irregularities in lens packing, internal mould. Based on Clarkson (1971). (e-f) Adult schizochroal eye of Eophacops trapeziceps (Barrande, 1846), Silurian, Bohemia, in (e) lateral and (f) dorsal views. Based on Thomas 1998.

to show the range in form of trilobite eyes, and of these, the amazing stalked holochroal eyes of some asaphids from the St Petersburg region (Wolchow river area) are especially noteworthy. It is well known that in most post-Cambrian trilobites, though not all, the visual surface is retained after death or moulting, being firmly attached to the eye socle. For most Cambrian trilobites (except for some of the olenids), however, this is not the case. This is because an additional suture is present, the ocular suture, which runs along the lower edge of the visual surface. This joins with the palpebral suture, so that in the adult a suture encircles the eye (forming the circumocular suture), which allows the visual surface to drop out from a dead animal or its moulted exuviae. It remains attached, however, in the meraspides, though these are not often preserved. A well-preserved specimen of Eoredlichia intermediata (Lu, 1940), from the Chengjiang Biota, retains the adult eye, with at least 30 lenses, forming a single line close to the palpebral suture (X.-g. Hou, pers. comm. 2014). The rest of the eye is damaged and the corneal membrane has been dissolved. This unusual specimen confirms that the earliest known trilobite eyes were typically holochroal.

Other recent studies have involved the use of the eye parameter to determine the relative depths at which different trilobites lived (McCormick \& Fortey 1998; Schoenemann et al. 2008a, 2010; Schoenemann \& Clarkson 2015; Tanaka et al. 2015).

In any compound eye, the visual surface is curved, so that each ommatidium points in a slightly different direction to its neighbours. The angle between the optical axes of two adjacent ommatidia, the interommatidial angle, is known as $\Delta \varphi$. For high acuity (i.e., maximum resolution and sharpness of the image), $\Delta \varphi$ needs to be as low as possible. But acuity also depends upon the number of lenses, and there are only limited numbers of these that can be accommodated on the visual surface, depending on the diameter of each ommatidium. The smaller the lenses, the fewer photons they can capture and, as such, are poorly adapted to dimly-lit environments. They must have a minimal diameter, defined as $D$. There is inevitably a trade-off between the requirements of light gathering (wide lenses, high $D$ ) and visual acuity (small lenses, low $\Delta \varphi$ ). These conflicting requirements are resolved in different ways by arthropods inhabiting different environments, and their eyes are optimised for their specific 'light-ecological' habitat. This can readily be determined, at least in relative terms, and even in fossil arthropods, by the eye parameter $D \cdot \Delta \varphi$, measured in $\mu \mathrm{rad}$.

Thus measurement of the diameter $D$ of lenses, and the curvature of the visual surface and the number of lenses upon it, or any other measurements to establish $\Delta \varphi$, will suffice to provide the necessary information. Using the eye parameter, McCormick \& Fortey (1998) and Tanaka et al. (2015) were able to show that two pelagic large-eyed cyclopygids swam at different depths in the ocean. Likewise, Schoenemann et al. (2008a, 2010) established that the tiny olenid Ctenopyge ceciliae Clarkson \& Ahlberg, 2002 was an inhabitant of well-illuminated shallow waters, and that the spiny olenids Sphaerophthalmus 
alatus (Boeck, 1938) and Ctenopyge (Mesoctenopyge) tumida Westergård, 1922, though found together in the same beds, were adapted to different light-ecological habitats (Schoenemann \& Clarkson 2015); the former living in a dimly-lit environment (most likely on the sea floor), the latter in a well-illuminated habitat (likely as a pelagic swimmer).

1.2.4. Schizochroal eyes. During the 270 million years of trilobite evolution, there is only one clade that made a radical, but evidently successful, departure from the holochroal system. This is the schizochroal eye (Fig. 3d-f), confined to the Lower Ordovician to Upper Devonian Suborder Phacopina, which persisted for about $130 \mathrm{Ma}$. In these eyes, the lenses are much larger and fewer than those of holochroal eyes, and they are separated one from another by 'interlensar sclera', effectively the same material as the rest of the exoskeleton (Clarkson 1967, 1997). The lens array surveys a visual field which is directed laterally, forwards and backwards, but never overhead. The large lenses have been shown to have a complex internal structure (Lindström 1901; Clarkson \& Levi-Setti 1975; Lee et al. 2012; Torney et al. 2014). Much attention has been given to the functioning of the schizochroal eye, which has no close resemblance to any other kind of visual organ in the whole of the animal kingdom (Horvath et al. 1997).

1.2.5. Origins of the schizochroal eye revisited. Trilobites grew by successive moults, and the discarded exuviae, and rare cadavers preserved in the fossil record, can be arranged in a gradational size series for many species, showing the whole course of ontogeny from larva to adult. In some exceptionally well-preserved meraspides of species that have holochroal eyes in the adult form, the tiny visual systems are preserved in fine detail. In several cases, notably the Cambrian Olenus (Clarkson \& Taylor 1995) and the Carboniferous Paladin (Clarkson \& Zhang, 1991) (Fig. 3a-c) the lenses are few, separated from one another and relatively large for the size of the visual surface. In other words, such an eye looks more like a schizochroal eye than an adult holochroal eye. This seems to have been the general trend for all holochroal eyes. In considering the origin of the schizochroal eye, the most likely first evolutionary step would have been via paedomorphosis, a simple mutation leading to the retention of the ancestral juvenile structure (or state) into the adult of the descendant. This appears to have happened by the early Ordovician in phacopids, which possess the first schizochroal eyes, though the origin of this group remains a classic case of cryptogenesis.

The origin of schizochroal eyes in early Ordovician phacopids is interesting in this regard. If their eyes developed as a result of paedomorphosis, they inherited from their holochroal ancestors a visual surface with relatively few, separated lenses that are large relative to the surface of the eye, but are all more-or-less the same size. It is known that in all trilobite eyes, whether holochroal or schizochroal, the visual surface grows forwards and downwards. Thomas $(1998,2005)$ proposed a model for how this may have happened, based on the living Drosophila. Here, during eye-formation, a 'morphogenetic furrow' sweeps across the imaginal disc, generating a 'wave' of lens emplacement running across the eye. Quite possibly, this is an ancient, conserved developmental programme, and may be common to all arthropods. The first row of (small) lenses in trilobites is emplaced just below the palpebral suture. This is most easily seen in the phacopids. Whilst the eye remains tiny there are only a few lenses, and these are preserved as the accessory upper horizontal row. In some of the large-eyed dalmanitids, there may actually be more than one such accessory row. Thus, lenses emplaced in alternate rows below existing lenses leads to a clear pattern of hexagonal close packing. But in some of the early Ordovician genera, such as Ormathops atavus (Barrande, 1872) (Fig. 3d) and Toletanaspis, the regularity of lens packing breaks down. Several examples of this were shown by Clarkson (1971); in some instances, within the same species, separate blocks of parallel files of identical-sized lenses are separated by discontinuities (caesurae), whilst in others, parts of the visual surface have the lenses arranged in an irregular and haphazard system. The packing arrangement is seldom the same in members of the same population, or even in the two eyes of a single individual. There is a good reason for this. The critical issue here is that the genetic programme for the growth of the visual surface is decoupled from that for lens emplacement. The downward expansion of the visual surface with growth, which would accommodate more lenses, conflicts with the emplacement of the lenses along dorso-ventral vectors. The result is an irregular emplacement. But in later phacopids, regularity is ensured by a small but regular downward increase in the spacing of the lens centres and a concomitant enlargement of the size of the lenses. This surely tells us that regularity of packing is important for the vision of schizochroal eyes, and this would accord well with the neural superposition scheme proposed by Schoenemann (2007). The irregular packing of the lenses in the Ormathops complex is one of the few imperfect adaptations that we see in trilobites.

1.2.6. New developments in the interpretation of schizochroal lenses. It is well established that (i) the original material of which all trilobite lenses are constructed is orientated calcite (Towe 1973; Clarkson 1997; Clarkson et al. 2006); (ii) the lenses of schizochroal eyes are internally differentiated into three separate components, the upper unit, the intralensar bowl, and the core (Clarkson 1967, 1969; Clarkson \& Levi-Setti 1975; Miller \& Clarkson 1980; Lee et al. 2012; Torney et al. 2014). The upper lens unit and the intralensar bowl form a doublet system with an aplanatic interface, bringing light to a sharp focus; and (iii) all trilobite eye lenses consist of slender, orientated calcitic microcrystallites known as trabeculae, which traverse the lens from top to bottom. That the calcite may show fluorescence which, however, is not of biological relevance, has been discussed recently (Schoenemann et. al. 2015).

Bruton \& Haas (2003) believed that all internal structures that had been recorded within the eyes of trilobites were artefacts. They proposed instead an interesting alternative theoretical concept, the Graded Refractive Index model. But the fact that the internal structures they illustrated are remarkably similar in each lens and, moreover, closely resembled those already described, did not lead to a general acceptance of the new hypothesis. Further proof of the primary nature of the upper unit, bowl and core came from the detailed mineralogical analyses of Lee et al. (2007) and Torney et al. (2014). They used various cutting-edge techniques, which gave an understanding of the structure of the calcitic lenses in detail never seen before. Although these authors acknowledge that these internal structures have undergone diagenetic alteration, they consider that there were indeed original differences in mineral chemistry between the upper lens unit and the bowl. Both the bowl and the core (which is primary) contain pervasive micropores and microdolomite inclusions, both products of replacement of original magnesian calcite. The bowl and core (but especially the former) were constructed of high magnesian calcite; in contrast with the upper lens unit, in which the magnesium content was lower. These studies confirm that there was indeed a chemical contrast between the upper unit and the other components, thus sustaining the doublet hypothesis. The rest of the trilobite exoskeleton is made of low-magnesian calcite, and the presence of high-magnesian calcite in the bowl and core clearly indicates a simultaneous crystallisation of both low and high magnesian calcite (Lee et al. 2007; Torney et al. 2014). These authors also note that such "a strong biological control on the chemical composition 

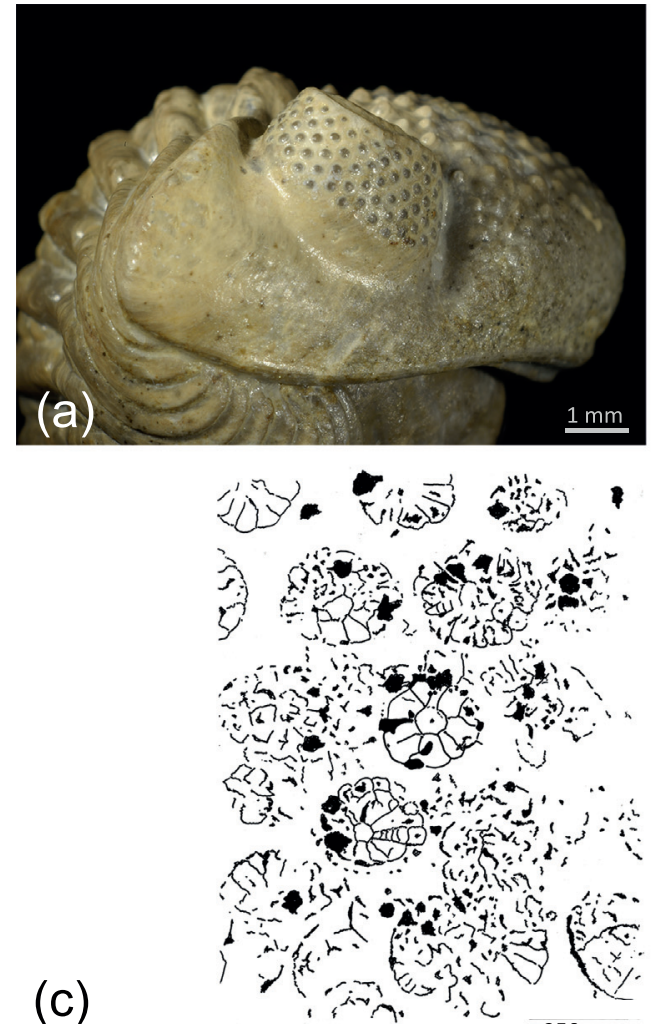

(c)

$250 \mu \mathrm{m}$

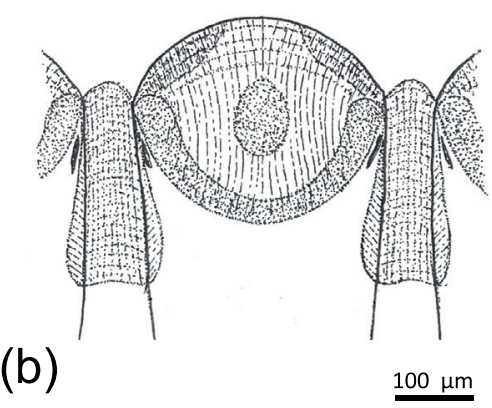

(d)

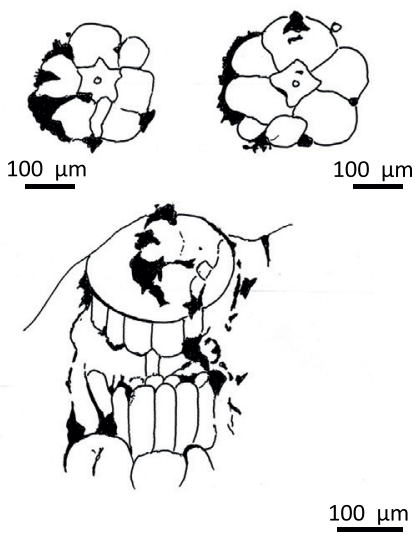

Figure 4 (a) Right schizochroal eye of an enrolled specimen of Geesops schlotheimi (Bronn, 1825), Middle Devonian, Gees-Gerolstein, Germany, showing lenses. (b) Vertical section through a lens of a schizochroal-eyed trilobite, with the capsule below, modified from Miller \& Clarkson (1980), with additions from Torney et al. (2014). (c, d) Sublensar structures in schizochroal eyes, redrawn from Schoenemann \& Clarkson (2013), revealing the original contents of capsules: (c) cross-section through the upper third of compound eye, showing preservation through mineral seeding on slightly rotted and disturbed original structures; (d) two well-preserved visual units in cross-section and vertical section through a visual unit, lying within the capsule. Redrawn from Schoenemann \& Clarkson (2013).

of calcite indicates that magnesium was necessary for the functioning of the optical system, most probably through its influence on the refractive index of calcite" (Lee et al. 2012, p.1036). The optical functions of various components of the lenses have been investigated by Horvath and his colleagues; the intralensar bowl reduces reflectivity (Horvath 1996), and the core appears to have been involved in image formation (Egri \& Horvath 2012).

A further development was proposed by Schoenemann \& Clarkson $(2008,2011)$. Although the classic model of Clarkson \& Levi-Setti (1975) holds for the majority of trilobites, there are others in which there appear to be gaps between adjacent trabeculae. If these, in life, had been filled with organic matter, then each trabeculum would have been isolated from its neighbours. A simple model was proposed for the generation of the organic sheath. If the trabecula had indeed been isolated in this way, then, as a result of total internal reflection, they would act as light guides, and thus the whole lens could act as a lightguide bundle. The result would be a pixelated visual system, unknown elsewhere in the animal kingdom, but with evident parallels with modern optical technology.

Torney et al. (2014) have proposed an elegant new model for the growth of the lenses. Distinguishing between lowconvexity (dalmanitid) and high-convexity (phacopine) lenses, their detailed analysis shows that the (often fan-like) trabeculae do not quite extend to the outer surface of the lens, where instead there is a radial fringe of very thin calcite sheets, either annular (Figs 4b, 5), or extending across the eye, whose c-axes lie at a low angle to the surface. In high-convexity lenses, the radial fringe is thicker, and the trabeculae seem to be absent.
Both kinds of lenses are regarded as having formed as a result of a migrating surface moving downwards from the cornea. Whether this concept bears upon the light-guide model remains debatable; we do not believe that it invalidates our model. But it illustrates the extraordinary complexity of the schizochroal eye and how much has already been revealed by modern technology; but also how much more remains to be done.

1.2.7. Sublensar structures in phacopid eyes. A significant development in our understanding of schizochroal eyes comes from the recent discovery of original sublensar sensory structures in the eyes of some Devonian phacopids (Figs 4a-d, 5).

It has been known for some time (Clarkson 1967, 1997; Miller \& Clarkson 1980; Clarkson et al. 2006) that below each lens lay a thin-walled capsule, usually with a flat base (Figs 4b, 5). Until now, nothing further was known. In the absence of further information, it was generally believed that a layer of sensory cells extended over the flat base and acted as a retina. When $\mu$-CT-scanning became generally available, it was possible to investigate trilobite eyes in a new way (Schoenemann et al. 2008b; Schoenemann \& Clarkson 2012d, 2013). Specimens of the Middle Devonian phacopids Geesops schlotheimi (Bronn, 1825) (Fig. 4a), Phacops latifrons (Bronn, 1825) from the Ahrdorf Formation at a locality between Gees and Gerolstein, Germany and Barrandeops cf. granulops (Chatterton et al. 2006) from the Ma'der region, Morocco, have revealed remarkable details of original sensory structures, preserved by the 'seeding' of mineral films over soft parts. When the latter rotted away, the mineral films remained. Tangential scans were made at different levels below the lenses, and the upper level revealed circular rosette structures, each 


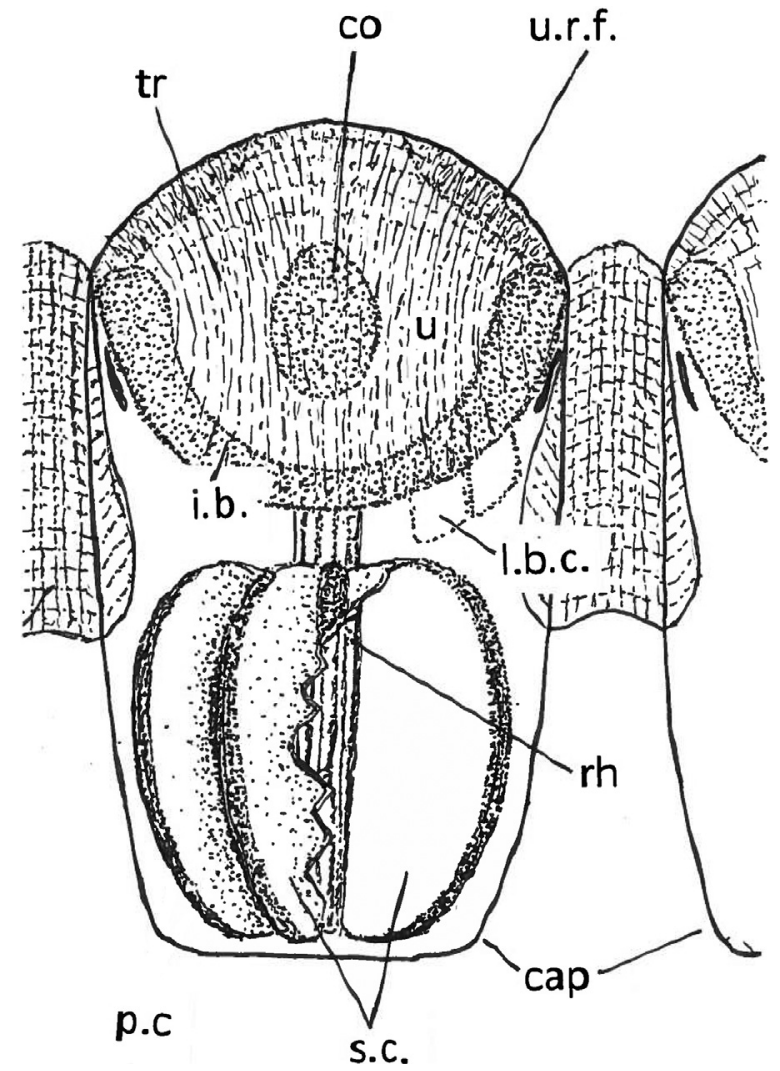

Figure 5 Schematic reconstruction of a lens of a schizochroal phacopid eye lens and capsule with contents. Lens modified from Miller \& Clarkson (1980), with additions from Torney et al. (2014). Contents of the capsule tentative, based on Schoenemann \& Clarkson (2013); see also Fig. 4d. Rhabdom covers (pigment?) cells and sensory cells. The positions of two of the lens-building (?) cells are shown on the right hand side. The sensory elements are shown cut away on the right hand side to show the flat inner face of a sensory cell; the left side is intact. Abbreviations: cap $=$ capsule; $c 0=$ core; i.b. $=$ intralensar bowl; 1.b.c. $=$ lens-building (?) cells; p.c $=$ pigment (?) cells; $\mathrm{rh}=$ rhabdom; sc = sensory cells; $\operatorname{tr}=$ trabeculae; $\mathrm{u}=$ upper lens-unit; u.r.f. $=$ upper radial fringe

below a corresponding lens. These are of constant form and are regularly arranged (Figs 4c, d, 5). A second scan at a lower level showed the same kind of structures, but the rosette array was more disturbed and broken. Each rosette, arranged around a central irregularly star-shaped unit, consists of an inner circlet of six or seven wedge-shaped cells, arranged like the segments of an orange, and an outer circlet of separate black patches, each set at the outer edge of the rosette, at the junction of the cells of the inner circlet. The central star-shaped unit is interpreted as a rhabdom, the large inner cells as the sensory cells and the black patches as pigment cells. Scans made in lateral view of the Geesops eye (Fig. 4d) show several square cells with rounded terminations, and a central rod, evidently connecting with the rhabdom, around which are elongated cells, probably the sensory cells encountered in the tangential scans, or possibly pigment cells. Some other structures shown in the lateral scan remain of unknown nature.

In a specimen of Barrandeops from Morocco, the sensory cells, forming rosettes, are again visible, but preserved by a film of silica (Klug et al. 2009). In another specimen of Chotecops, the sensory structures are pyritised and visible where the external lentiferous surface has been stripped off. These largely confirm what has been established by CT scanning.

Whereas, as mentioned earlier, the sensory cells were thought to be arranged as a retina, these recent investigations show clearly, if unexpectedly, that the sublensar structures much more closely resemble ommatidia, as in euarthropod apposition eyes, and particularly that of living Limulus, though much larger.

1.2.8. Eodiscid eyes. The Order Eodiscida is a group of small trilobites with only two or three thoracic segments. They are confined to the lower and middle Cambrian. Their eyes have been defined as abathochroal (Jell 1975). This is similar to a holochroal eye, although the lenses may be somewhat separated from each other. If each lens carried its own cornea, then the abathochroal eye could be considered as a separate eye type, though this cannot be proven, and most authorities today regard the eodiscid visual system as merely another kind of holochroal eye (Clarkson et al. 2006). Eodiscid eyes are best known from phosphatised material from the lower Cambrian of China and the middle Cambrian of Australia; it is a curious fact that, despite the elegance of these eyes, many of the later eodiscids lost their visual systems altogether, for reasons which remain unknown. The eyes of many Chinese species have been studied in detail and fully illustrated elsewhere (see Zhang 1989; Zhang \& Clarkson 1990, 1993, 2012).

\subsection{Résumé and perspective}

As this article shows, there is a rich record of fossil eyes that extends continuously throughout most of the Phanerozoic from the lower Cambrian to the present day. However, the origin and evolution of vision had been a vexing problem, even for Darwin. He confessed that it was 'absurd' to propose that a structure as complex as the human eye could have evolved just as a result of natural selection. He found a solution, however, postulating a gradual development from "an optic nerve merely coated with pigment, and without any other mechanism" towards a "moderately high stage of perfection", and indicated a sequence of examples of eyes with increasing complexity (Darwin 1859, Chapter 6). Zoologists took up his ideas directly, and produced models explaining and illustrating the pathways which led from a very simple photosensory cell, accompanied by a certain amount of pigment, to high resolving systems such as camera or compound eyes (e.g., Gehring 2005; Nilsson 2013; Randel \& Jékely 2016). There had been some attempts to show the evolution of complex eyes by using morphology and the fossil record alone (Young 2008). There was, however, a general consensus that the fossil record could hardly support any explanation of the evolution of eyes, because usually no soft tissues, such as nerves, sensory cells or other contributing elements of a functional eye are preserved during fossilisations. A first suggestion of how that could be challenged was given at an international conference in Nanjing (Schoenemann 2005).

Clarkson \& Levi-Setti (1975) had shown, following the remarkable discoveries of Lindström in 1901 on the lenses of phacopid trilobite eyes, that it was indeed possible to analyse complex structures of fossilised lenses. A new perspective opened up, restoring faith in the credibility of using the fossil record to develop an understanding of at least some aspects of the evolution of visual systems through time.

The analysis of the visual systems of the lower Cambrian Chengjiang fauna, up to then regarded as 'black spots', was a first step forward. As noted here, the analysis of lobopodian eyes (Schoenemann \& Clarkson 2010) as a one-lens system was the first functional analysis of a Cambrian visual system. The existence of compound eyes, probably high resolving, during the Cambrian was clear from the fossils of arthropod eyes from the Emu Bay (Lee et al. 2011; Paterson et al. 2011), and even morphological differentiation within the visual surface of complex compound eyes became apparent (Zhao et al. 2013). By adapting the physical tools (Horridge 1977, 1978; Snyder 
1977, 1979; Land 1981) developed to describe the performances of extinct systems, it was possible to develop further differentiated insights into vision in the Cambrian. It was possible in such a way to assign the organisms of the Chengjiang fauna to their original habitats, by estimating their eye parameter and sensitivity (Schoenemann \& Clarkson 2010, 2011, 2012a, b, c); whilst the results were in good accordance with the palaeoecological interpretations of the Chengjiang biota of Chen \& Zhou (1997). As shown here, the eye parameter had been applied in trilobites before (Fordyce \& Cronin 1989, 1993; McCormick \& Fortey 1998). Its successful application, even to Cambrian arthropods, seems to have triggered a number of analyses of fossil compound eye systems in other arthropods of Cambrian time (Zhao et al. 2013), trilobites (Schoenemann \& Clarkson 2015; Tanaka et al. 2015), crustaceans (Schoenemann \& Clarkson 2012a, b, c; Rust et al. 2016; Vannier et al. 2016) and eurypterids (Anderson et al. 2014; Poschmann et al. 2016). It may be concluded that this is indeed an effective way of investigating the structural parameters in the eyes of fossils. From early Cambrian times, we have simple compound eyes with spherical dioptric units and complex hexagonal patterns of facets, and we find one-lens systems such as in the lobopodians, or the median eyes of euarthropods, as discussed above.

The disadvantage for any model about the evolution of eyes, especially when considering those of extinct organisms, and the incomplete nature of the fossil record, is that one cannot be overly confident about what actually happened during the course of time; thus the conclusions remain purely hypothetical. A recent breakthrough came when the sensory structures of phacopid compound eyes were first made visible by $\mu-C T$ and synchrotron analyses (Schoenemann et al. 2008b, 2010; Schoenemann \& Clarkson 2012d, 2013). Even if these structures are still not completely understood, this work opened the way for studying preserved soft tissues of eye structures to understand their function, internal complexity and evolutionary significance. In 2014, Tanaka et al. were able to show the rods and cones inside a fish retina, indicating that this fish possessed colour vision. Other recent discoveries by Strausfeld and co-workers showed that in at least some Chengjiang fossils, the delicate architecture of arthropod brains can be preserved, including the optical lobes (Ma et al. 2012; Cong et al. 2014; Strausfeld et al. 2015). This gave the potential for further progress into analysing the relationships amongst Cambrian arthropods and modern organisms. The future holds the potential for inclusion of valuable data from the fossil record - especially that derived from modern technologies - in developing new perspectives on the evolution of vision. This, more than any models referring to Recent organisms alone, will allow us to better understand how eyes originated and evolved, and even solve some long-standing evolutionary conundrums (e.g., Clements et al. 2016), because we have the witnesses posted along the long axis of evolutionary time.

\section{Acknowledgements}

We thank Catherine Crônier and an anonymous reviewer for their careful reviews and helpful comments; Oskar Fischer for his assistance with Figure 1; and William Crighton for taking the photograph of Geesops in Figure 4a.

\section{References}

Adrain, J. M., Fortey, R. A. \& Westrop, S. R. 1998. Post-Cambrian trilobite diversity and evolutionary faunas. Science 280, 1922-25.

Anderson, R. P., McCoy, V. E., McNamara, M. E. \& Briggs, D. E. G. 2014. What big eyes you have: the ecological role of giant pterygotid eurypterids. Biology Letters 10, 20140412.
Barrande, J. 1846. Notice preliminaire sur le Systeme Silurien de la Boheme. Leipzig: Hirschfeld. 96 pp.

Barrande, J. 1872. Système Siluriken du Centre de la Bohème. Iere Partie, Supplement au vol. 1, Trilobites, Crustaces et poissons. (Praha, Paris). $637 \mathrm{pp}$.

Boeck, C. 1838. Uebersicht der bisher in Norwegen gefundenen Formen der Trilobiten-Familie. 138-145. In Keilhau, B. M. (ed.) Gaea norvegica, Vol. 1. Christiania: Johann Dahl. 148 pp.

Briggs, D. E. G. \& Clarkson, E. N. K. 1985. The Lower Carboniferous shrimp Tealliocaris from Gullane, East Lothian, Scotland. Transactions of the Royal Society of Edinburgh: Earth Sciences 76, 173202.

Briggs, D., Erwin, D. H. \& Collier, F. J. 1994. The Fossils of the Burgess Shale. Washington, DC: Smithsonian Books. 256 pp.

Bronn, H. 1825. Über zwei neue Trilobiten-Arten zum Calymene Geschlechte gehörig. Zeitschrift für Mineralogie 1, 317-21.

Bruton, D. J. \& Haas, W. 2003. The puzzling eye of Phacops. Special Papers in Palaeontology 70, 349-61.

Campbell, K. S. W. 1975. The functional anatomy of phacopid trilobites: musculature and eyes. Journal and Proceedings of the Royal Society of New South Wales 108, 168-88.

Chatterton, B. D. E., Fortey, R. A., Brett, K., Gibb, S. \& Kellar, R. M. 2006. Trilobites from the upper Lower to Middle Devonian Timrhanrhart Formation, JbelGara el Zguilma, southern Morocco. Palaeontographica Canadiana 24, 1-177.

Chen, J. Y., Huang, D. Y. \& Li, C. W. 1999. An Early Cambrian craniate-like chordate. Nature 402, 518-22.

Chen, J. Y. \& Zhou, G. Q. 1997. Biology of the Chengjiang fauna. National Museum of Natural History Bulletin 10, 11-105.

Clarke, J. M. 1889. The structure and development of the visual area in the trilobite, Phacops rana, Green. Journal of Morphology 2, 253-70.

Clarkson, E. N. K. 1967. Fine structure of the eye in two species of Phacops (Trilobita). Palaeontology 10, 603-16.

Clarkson, E. N. K. 1969. On the schizochroal eyes of three species of Reedops (Trilobita; Phacopida from the Lower Devonian of Bohemia. Transactions of the Royal Society of Edinburgh: Earth Sciences 68, 183-205.

Clarkson, E. N. K. 1971. On the early schizochroal eyes of Ormathops (Trilobita, Zeliszkellinae). Mémoires du Bureau des Recherches Géologiques et Minières 73, 51-63.

Clarkson, E. N. K. 1975. The evolution of the eye in trilobites. Fossils \& Strata 4, 7-31.

Clarkson, E. N. K. 1979. The visual system of trilobites. Palaeontology 22, 1-22.

Clarkson, E. N. K. 1997. The Eye: Morphology and Function. In Moore, R. C. \& Kaesler, R. L. (eds) Treatise on Invertebrate Palaeontology, Part O, Arthropoda 1, Trilobita Revised Vol. 1, 114-32. Boulder, Colorado and Lawrence, Kansas: The Geological Society of America and University of Kansas Press.

Clarkson, E. N. K. 1998. Invertebrate Palaeontology and Evolution. (Fourth Edition). Oxford: Blackwell Science. 452 pp.

Clarkson, E. N. K. 2013. Trilobites. In McLeod, N. (ed.) Grzimek's Animal Life Encyclopaedia, vol 13. Extinctions, 235-44. Detroit: Gale. Cengage Learning. 964 pp.

Clarkson, E. N. K., Levi-Setti, R. \& Horvath, G. 2006. The eyes of trilobites: the oldest preserved visual system. Arthropod Structure and Development 34, 247-60.

Clarkson, E. N. K., Levi-Setti, R. \& Horvath, G. 2008. Los ojos de los trilobitos; el sistema visual mas antiguo conservada. iFundamental! 13, 1-70.

Clarkson, E. N. K. \& Ahlberg, P. 2002. Ontogeny and structure of a new, miniaturised and spiny olenid trilobite from southern Sweden. Palaeontology 45, 1-22.

Clarkson, E. N. K. \& Levi-Setti, R. 1975. Trilobite Eyes and the Optics of Des Cartes and Huygens. Nature 254, 663-67.

Clarkson, E. N. K. \& Taylor, C. M. 1995. Ontogeny of the trilobite Olenus wahlenbergi Westergård, 1922 from the upper Cambrian Alum Shales of Andrarum, Skåne, Sweden. Transactions of the Royal Society of Edinburgh: Earth Sciences 86, 13-34.

Clarkson, E. N. K. \& Zhang, X. G. 1991. Ontogeny of the Carboniferous trilobite Paladin eichwaldi shunnerensis (King, 1914). Transactions of the Royal Society of Edinburgh: Earth Sciences 82, 277-96.

Clements, T., Dolocan A., Martin, P., Purnell, M. A., Vinther, J. \& Gabbott, S. E. 2016. The eyes of Tullimonstrum reveal a vertebrate affinity. Nature 532, 500-03.

Cong, P., Ma, X. Y., Hou, X., Edgecombe, G. D. \& Strausfeld, N. J. 2014. Brain structure resolves the segmental affinity of anomalocaridid appendages. Nature 513, 538-42.

Crônier, C., Malti, F. Z., François, A., Benyoucef, M. \& Brice, D. 2013. First occurrence of a phacopid trilobite faunule from the 
Upper Devonian of Saoura Valley, Algeria and biodiversity fluctuations. Geological Magazine 150, 1002-21.

Crônier, C. \& Courville, P. 2003. Variations du rythme du développement chez les trilobites Phacopidae néodévoniens. Comptes Rendus Palevol 2, 577-85.

Crônier, C. \& François, A. 2014. Distribution patterns of Upper Devonian phacopid trilobites: Paleobiogeographical and paleoenvironmental significance. Palaeogeography, Palaeoclimatology, Palaeoecology 404, 12-23.

Cronin, T. W., Johnson, S., Marshall, N. J. \& Warrant, E. J. 2012. Visual Ecology. Oxford \& Princeton: Princeton University Press. $405 \mathrm{pp}$.

Darwin, C. 1859. The origin of species by natural selection, or the preservation of favoured races in the struggle for life. London: $\mathbf{J}$. Murray.

Egri, A. \& Horvath, G. 2012. Possible optical functions of the central core in lenses of trilobite eyes: spherically corrected monofocality or bifocality. Journal of the Optical Society of America A 27, $1965-76$.

Feist, R. 1991. The Late Devonian trilobite crises. Historical Biology 5, 197-214

Feist, R. \& Clarkson, E. N. K. 1989. Environmental controlled phyletic evolution, blindness and extinction in Late Devonian tropidocoryphine trilobites. Lethaia 22, 359-73.

Fordyce, D. \& Cronin, T. W. 1989. Comparison of fossilised schizochroal compound eyes of phacopid trilobites with eyes of modern marine crustaceans and other arthropods. Journal of Crustacean Biology 9, 554-69.

Fordyce, D. \& Cronin, T. W. 1993. Trilobite Vision: a comparison of schizochroal and holochroal eyes with the compound eyes of modern arthropods. Palaeobiology 19, 288-303.

Fortey, R. A. 1985. Pelagic trilobites as an axample of deducing the life habits of ancient arthropods. Transactions of the Royal Society of Edinburgh: Earth Sciences 76, 219-30.

Fortey, R. A. 2000. Trilobite! Eyewitness to Evolution. London: Harper Collins. 269 pp.

Fortey, R. A. \& Owens, R. M. 1997. Evolutionary History. In Kaesler, R. L. (ed.) Treatise on Invertebrate Paleontology, Part O, Arthropoda 1, Trilobita, revised. Volume 1: Introduction, Order Agnostida, Order Redlichiida, 249-87. Boulder, Colorado \& Lawrence, Kansas: The Geological Society of America and University of Kansas Press.

Gehring, W. J. 2005. New perspectives on Eye Development and the Evolution of Eyes and Photoreceptors. Journal of Heredity 96, $171-84$.

Gehring, W. J. \& Seimiya, M. 2010. Eye evolution and the origin of Darwin's eye prototype. Italian Journal of Zoology 77, 124-36.

Horridge, G. A. 1977. Insects which turn and look. Endeavour 1, 7 17.

Horridge, G. A. 1978. The Separation of Visual Axes in Apposition Compound Eyes. Philosophical Transactions of the Royal Society of London, Series B, Biological Sciences 285(1003), 1-59.

Horváth, G. 1996. The lower lens unit in schizochroal trilobite eyes reduces reflectivity: On the possible optical function of the intralensar bowl. Historical Biology 12, 83-92.

Horváth, G., Clarkson, E. N. K. \& Pix, W. 1997. Survey of modern counterparts of schizochroal trilobite eyes. Historical Biology 12 229-63.

Hou, X.-g., Aldridge, R. J., Bergstrom, J., Siveter, D. J., Siveter, D. J., \& Feng, X. H. 2004. The Cambrian fossils of Chengjiang, China: the flowering of early animal life. Oxford: Blackwell Publishing. $233 \mathrm{pp}$

Jell, P. A. 1975. The abathochroal eye of Pagetia: a new type of trilobite eye. Fossils \& Strata 4, 33-43.

Jiang, Z.-W. 1982. [Small shelly fossils.] In Luo, H. L., Jiang, Z. W. $\mathrm{Wu}, \mathrm{X} . \mathrm{C}$, Song, X. L. \& Ouyang, Lin (eds) [The SinianCambrian boundary in Eastern Yunnan, China], 163-99. People's Publishing House of Yunnan. [In Chinese.]

Khaldi, A., Crônier, C., Hainaut, G., Abbache, A. \& Ouali Mehadji, A. 2016. A trilobite faunule from the Lower Devonian of the Saoura Valley, Algeria: biodiversity, morphological variability and palaeobiogeographical affinities. Geological Magazine 153(3), 357-87.

King, W. B. R. 1914. A new trilobite from the Millstone Grit of North Yorkshire. Geological Magazine 63, 390-94.

Klug, C., Schulz, H. \& De Baets, K. 2009. Red Devonian trilobites with green eyes from Morocco and the silicification of the trilobite exoskeleton. Acta Palaeontologia Polonica 53, 117-23.

Land, M. F. 1981. Optics and vision in invertebrates. In Autrum, H.-J. (ed.) Handbook of Sensory Physiology VII/6B, 471-592. Berlin: Springer.

Land, M. F. \& Nilsson, D.-E. 2012. Animal Eyes. Oxford, UK: Oxford University Press. 220 pp.
Lee, M. R., Torney, C. \& Owen, A. W. 2007. Magnesium-rich intralensar structures in schizochroal trilobite eyes. Palaeontology 50, $1031-37$.

Lee, M. S. Y., Jago, J. B., Garcia-Bellido, D. C., Edgecombe, G. D., Gehling, J. \& Paterson, J. R. 2011. Modern optics in exceptionally preserved eyes of Early Cambrian arthropods from Australia. Nature 474, 631-37 + suppl.

Lee, M. R., Torney, C. \& Owen, A. W. 2012. Biomineralisation in the Palaeozoic oceans: evidence for simultaneous crystallization of high and low magnesium calcite by phacopid trilobites. Chemical Geology 33-34, 314-17.

Levi-Setti, R. 2014. The trilobite book. University of Chicago Press, $267 \mathrm{pp}$

Levi-Setti, R., Clarkson, E. N. K. \& Horvath, G. 1998. Paleontologia dell' occhi. In Frontiere della vita. Enciclopedia Italiana, 365-79.

Lindström, G. 1901. Researches on the visual organs of trilobites Kungliga Svenska Vetensk-Akademiens Handlingar 34, 1-89.

Lu, Y. H. 1940. On the ontogeny and phylogeny of Redlichia intermedia $\mathrm{Lu}$ (sp. nov.). Bulletin of the Geological Society of China 20, $333-42$.

Ma, X. Y., Hou, X. G., Edgecombe, G. D. \& Strausfeld, N. J. 2012 Complex brain and optic lobes in an early Cambrian arthropod. Nature 490, 258-61.

Martin, M. W., Grazhdankin, D. V., Bowring, S. A., Evans, D. A. D. Fedonkin, M. A. \& Kirschvink, J. L. 2000. Age of Neoproterozoic Bilaterian Body and Trace Fossils, White Sea, Russia: Implications for Metazoan Evolution. Science 288, 841-45.

McCormick, T. \& Fortey, R. A. 1998. Independent testing of a paleobiological hypothesis; the optical design of two Ordovician pelagic trilobites. Paleobiology 24, 235-53.

McKellar, R. \& Chatterton, B. D. E. 2009. Early and Middle Devonian Phacopidae (Trilobita) of southern Morocco. Palaeontographica Canadiana 28, 1-110.

Miller, J. \& Clarkson, E. N. K. 1980. The post-ecdysial development of the cuticle and the eye in Phacops rana milleri Stewart, 1927. Philosophical Transactions of the Royal Society, London (Series B) 288, 461-80.

Müller, K. J. 1983. Crustacea with soft parts from the Upper Cambrian of Sweden. Lethaia 63, 93-109.

Müller, K. J. \& Walossek, D. 1985. Skaracarida, a new order of Crustacea from the Upper Cambrian of Vaestergoetland. Fossils \& Strata 17, 1-65.

Nilsson, D.-E. 2009. The evolution of eyes and visually guided behaviour. Philosophical Transactions of the Royal Society of London 364, 2833-47.

Nilsson, D.-E. 2013. Eye evolution and its functional basis. Visual Neuroscience 30, 5-20.

Pallas, P. S. 1774. Spicilegia zoologica, quibus novae imprimis et obscurae animalium species iconibus, descriptionibus atque commentariis illustrantur cura P.S. Pallas. Berolini. Fasciculus 10, Lange, G. A. (ed.), pp 1-41.

Parker, A. 2003. In the blink of an eye. Cambridge, Massachusetts: Perseus. 316 pp.

Parker, A., Schoenemann, B., Haug, J. T. \& Waloszek, D. 2013. An unusual cornea from a well-preserved ('Orsten') Cambrian compound eye. Palaeontological Research 17, 251-60.

Paterson, J. R., García-Bellido, D. C., Lee, M. S. Y., Brock, G. A., Jago, J. B. \& Edgecombe, G. D. 2011. Acute vision in the giant Cambrian predator Anomalocaris and the origin of compound eyes. Nature 480, 237-40, + suppl

Paterson, J. R., García-Bellido, D. C., Jago, J. B., Gehling, J. G., Lee, M. S. Y. \& Edgecombe, G. D. 2016. The Emu Bay Shale KonservatLagerstätte: A view of Cambrian life from East Gondwana. Journal of the Geological Society, London 173, 1-11.

Peel, J \& Ineson, J. R. 2011. The extent of the Sirius, Passet Lagerstaette (early Cambrian) of North Greenland. Bulletin of Geosciences 86(3), 535-43.

Peng, S., Babcock, L. E. \& Cooper, R. A. 2012. The Cambrian Period. In Gradstein, F. M., Ogg, J. G., Schmitz, M. D. \& Ogg, G. M. (eds) The Geologic Time Scale 2012, Volume 2, 437-88. Amsterdam: Elsevier.

Poschmann, M., Schoenemann, B. \& McCoy, V. E. 2016. Telltale eyes: the lateral visual systems of Rhenish Lower Devonian eurypterids (Arthropoda, Chelicerata) and their palaeobiological implications Palaeontology 59, 295-304.

Ramsköld, L., Chen J. Y., Edgecombe, G. D. \& Zhou, G. Q. 1997. Cindarella and the arachnate clade Xandarellida (Arthropods, Early Cambrian) from China. Transactions of the Royal Society of Edinburgh: Earth Sciences 88, 19-38.

Randel, N. \& Jékely, G. 2016. Phototaxis and the origin of visual eyes. Philosophical Transactions B 371, 20150042. 
Rozanov, A. Y., Zhu, M., Pak, K. L. \& Parkhaev, P. Y. 2008. The 2nd Sino-Russian Symposium on the Lower Cambrian Subdivision. Paleontological Journal 42, 441-46.

Rudkin, D. A., Young, G. A., Elias, R. J. \& Dobrzanske, E. P. 2003. The world's biggest trilobite: Isotelus rex new species from the Upper Ordovician of northern Manitoba, Canada. Palaeontology 70, 99-112.

Rust, J., Bergmann, A., Bartels, C., Schoenemann, B., Sedlmeier, S. \& Kühl, G. 2016.?The Hunsrück biota: A unique window into the ecology of Lower Devonian arthropods. Arthropod Structure and Development $\mathbf{4 5}, 140-51$.

Schoenemann, B. 2005.The Cambrian Sight of View - Suggestions to Investigate Eyes of the Chengjiang Fauna by Comparison with Recent Visual Systems. Acta Micropalaeontologica Sinica 22, 16970.

Schoenemann, B. 2007. Trilobite eyes and a new type of neural superposition eye in an ancient system. Palaeontographica $A$ 281, 6391.

Schoenemann, B. 2013. The eyes of a tiny 'Orsten' crustacean - A compound eye at receptor level? Vision Research 76, 89-93.

Schoenemann, B., Clarkson, E. N. K. \& Franz, A. 2008a. Sublensar Capsules in Trilobite Eyes. In Rábano, I., Gozalo Gutiérrez, R. \& García-Bellido, D. (eds) Advances in Trilobite Research. Publicaciones del Instituto geólogico y minero de España 9, 356-51. Madrid: Instituto Geológico y Minero de España.

Schoenemann, B, Clarkson, E. N. K., Ahlberg, P. \& Dies Álvarez, M. E. 2008b. A Furongian Polymerid Planktonic Trilobite. In Rábano I., Gozalo Gutiérrez R. \& García-Bellido D. (eds) Advances in Trilobite Research. Publicaciones del Instituto geólogico y minero de España 9, 361-65. Madrid: Instituto Geológico y Minero de España.

Schoenemann, B., Liu, J. N., Shu D. G., Han J. A. \& Zhang Z. F. 2009. A Miniscule Optimised Visual System in the Lower Cambrian. Lethaia, 42, 265-273.

Schoenemann, B., Clarkson E. N. K., Ahlberg, P. \& Dies-Alvarez, M. E. 2010. A tiny eye indicating a planktonic trilobite. Palaeontology 53, 695-701.

Schoenemann, B., Castellani, C., Clarkson, E. N. K., Haug, J., Maas., A. Haug, C. \& Waloszek, D. 2011. The sophisticated visual system of a tiny Cambrian crustacean eye; analysis of a stalked fossil compound eye. Proceedings of the Royal Society B 279 1335-40.

Schoenemann, B., Clarkson, E. N. K., Castellani, C., Waloszek, D., Maas, A. \& Meyer-Rochow, V. B. 2014. Description and interpretation of the internal structure of a Cambrian crustacean compound eye. Bulletin of Geosciences 89, 311-24.

Schoenemann, B., Clarkson, E. N. K. \& Horváth, G. 2015. Why did the UV-A-induced photoluminescent blue-green glow in trilobite eyes and exoskeletons not cause problems for trilobites? PeerJ 3, e1492. doi:107717/peerj.1492.

Schoenemann, B. \& Clarkson, E. N. K. 2008. Did the trabecula in phacopid lenses act as light-guides? In Rábano, I., Gozalo Gutiérrez, R. \& García-Bellido, D. (eds) Advances in Trilobite Research. Publicaciones del Instituto geólogico y minero de España $\mathbf{9}$, 351-55. Madrid: Instituto Geológico y Minero de España.

Schoenemann, B. \& Clarkson, E. N. K. 2010. Eyes and vision in the Chengjiang arthropod Isoxys, indicating adaptation to habitat. Lethaia 44, 223-30.

Schoenemann, B \& Clarkson, E. N. K. 2011. Light guide lenses in trilobite eyes? Earth and Environmental Science Transactions of the Royal Society of Edinburgh 102, 17-21.

Schoenemann, B. \& Clarkson, E. N. K. 2012a. At First Sight Functional Analysis of Lower Cambrian Eye Systems. Palaeontographica $A$ 296, 1-27.

Schoenemann, B. \& Clarkson, E. N. K. 2012b. The eyes of Leanchoilia. Lethaia 45, 524-31.

Schoenemann, B. \& Clarkson, E. N. K. 2012c. Compound Eyes in the Chengjiang Biota. Acta Universitatis Latviensis, Earth and Environmental Sciences 783, 57-71.

Schoenemann, B. \& Clarkson E. N. K. 2012d. Insights to Phacopid Eyes. Acta Universitatis Latviensis, Earth and Environmental Sciences $\mathbf{7 8 3}$, $72-75$.

Schoenemann, B. \& Clarkson, E. N. K. 2013. Discovery of some 400 million year old sensory structures in the compound eyes of trilobites. Scientific Reports 3, 1429. Doi: 10.1038/srep01429.

Schoenemann, B. \& Clarkson, E. N. K. 2015. Eyes and vision in the coeval Furongian trilobites Sphaerophthalmus alatus (Boeck, 1838) and Ctenopyge (Mesoctenopyge) tumida Westergård 1922. Palaeontology 58, 133-40.
Sheehan, P. M. 2001. The Late Ordovician Mass Extinction. Annual Review of Earth and Planetary Sciences 29(1), 331-64.

Shu, D. G., Luo, H. L., Conway Morris, S., Zhang, X. L., Hu, S. X., Chen, L., Han, J., Zhu, M. Y., Li, Y. \& Chen, L. Z. 1999. Lower Cambrian vertebrates from south China. Nature 402, 42-46.

Snyder, A. W. 1977. Acuity of compound eyes, physical limitations and design. Journal of Comparative Physiology 116, 161-82.

Snyder, A. W. 1979. Physics of vision in compound eyes in vision in invertebrates. In Autrum, H. (ed.) Handbook of Sensory Physiology 7/6A, 213-313. Berlin: Springer.

Snyder, A. W., Stavenga, D. G. \& Laughlin, S. B. 1979. Spatial information capacity of compound eyes. Journal of Comparative Physiology 116, 183-207.

Strausfeld, N. J., Ma, X. Y., Edgecombe, G. D., Fortey, R. A., Land, M. F., Liu, Y., Cong, P. Y. \& Hou, X. G. 2015. Arthropod eyes: The early Cambrian fossil record and divergent evolution of visual systems. Arthropod Structure and Development 45, 152-72.

Tanaka, G., Parker, A. R., Siveter, D. J., Maeda, H. \& Furutani, M. 2009. An exceptionally well-preserved Eocene dolichopodid fly eye: function and evolutionary significance. Proceedings of the Royal Society of London, Section B 276, 1015-19.

Tanaka, G., Parker, A. R., Hasegawa, Y., Siveter, D. J., Yamamoto, R., Miyashita, K., Takahashi, Y., Ito, S., Wakamatsu, K., Mukuda, T., Tomokawa, K., Furutani, M., Suzuki, K. \& Maeda, H. 2014. Mineralized rods and cones suggest colour vision in a 300?Myr-old fossil fish. Nature Communications 5, 5920. doi:10.1038/ncomms6920.

Tanaka, G., Schoenemann, B., El Hariri, K., Ono, T., Clarkson, E. N. K. \& Maeda, H. 2015. Vision in a Middle Ordovician trilobite eye. Palaeogeography, Palaeoclimatology, Palaeoecology 433, 129-39.

Thomas, A. T. 1998. Variation in the eyes of the Silurian trilobites Eophacops and Acaste and its significance. Palaeontology 41, 897911.

Thomas, A. T. 2005. Developmental palaeobiology of trilobite eyes and its evolutionary significance. Earth Science Reviews 71, 7792.

Torney, C, Lee, M. R. \& Owen, A. W. 2014. Microstructure and growth of the lenses of schizochroal trilobite eyes. Palaeontology 57, 783-800.

Towe, K. 1973. Trilobite eyes; calcified lenses in vivo. Science 179, 1007-09.

Vannier, J., Schoenemann, B., Gillot, T., Charbonnier, S. \& Clarkson, E. N. K. 2016. Exceptional preservation of eye structure in arthropod visual predators from the Middle Jurassic. Nature Communications 7, 10320. doi:10.1038/ncomms10320.

Vannier, J. \& Chen, J. Y. 2000. The early Cambrian colonisation of pelagic niches exemplified by Isoxys (Arthropoda). Lethaia 33, 295-311.

Walcott, C. D. 1890. The fauna of the Lower Cambrian or Olenellus Zone. Reports of the US Geological Survey 10, 509-763.

Walcott, C. D. 1912. Cambrian geology and paleontology, 2. Middle Cambrian Branchiopoda, Malacostraca, Trilobita and Merostomata. Smithsonian Miscellaneous Collections 57, 145-228.

Webster, M. 2007. A Cambrian peak in morphological variation within trilobite species. Science 317(5837), 499-502.

Westergård, A. H. 1922. Sveriges olenidskiffer. Sveriges Geologiske Undersokning, ser. C 18. 205 pp.

Young G. 2008. Early Evolution of the Vertebrate Eye -Fossil Evidence. Evolution, Education and Outreach 1, 427-38.

Zhang, X. G. 1989. Ontogeny of an Early Cambrian eodiscoid trilobite from Henan, China. Lethaia 22, 13-29.

Zhang, X. G. \& Clarkson, E. N. K. 1990. The eyes of Lower Cambrian eodiscid trilobites. Palaeontology 33, 911-32.

Zhang, X. G. \& Clarkson, E. N. K. 1993. Ontogeny of the eodiscid trilobite Shizhudiscus longquanensis from the lower Cambrian of China. Palaeontology 36, 785-806.

Zhang, X. G. \& Clarkson, E. N. K. 2012. Phosphatised eodiscids from the Cambrian of China. Palaeontographica A 297, 1-121.

Zhang, X. L., Wei, L. \& Yuanlong, Z. 2008. Cambrian Burgess Shaletype Lagerstätten in South China: Distribution and significance. Gondwana Research 14, 255-62.

Zhao, F., Bottjer, D. J., Hu, S., Yin, Z. \& Zhu, M. 2013. Complexity and diversity of eyes in Early Cambrian ecosystems. Scientific Reports 3, 2751. doi: 10.1038/srep02751 1.

Zidek, J. 1976. Kansas Hamilton Quarry (Upper Pennsylvanian) Acanthodes, with remarks on the previously reported North American occurrences of the genus. The University of Kansas Paleontological Contributions 83, 1-41. 